\title{
No-Drop Prosecution of Domestic Violence: Just Good Policy, or Equal Protection Mandate?
}

\author{
Kalyani Robbins \\ Florida International University College of Law, krobbins@fiu.edu
}

Follow this and additional works at: https://ecollections.law.fiu.edu/faculty_publications

Part of the Courts Commons, Criminal Law Commons, and the Fourteenth Amendment Commons

\section{Recommended Citation}

Kalyani Robbins, No-Drop Prosecution of Domestic Violence: Just Good Policy, or Equal Protection Mandate? , 52 Stan. L. Rev. 205 (1999).

Available at: https://ecollections.law.fiu.edu/faculty_publications/262 


\section{HEINONLINE}

Citation: 52 Stan. L. Rev. 205 1999-2000

Provided by:

FIU College of Law

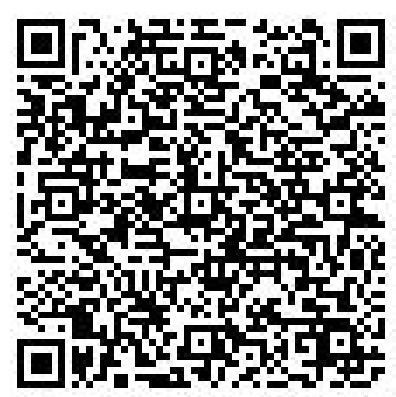

Content downloaded/printed from HeinOnline

Tue Nov 22 15:14:14 2016

-- Your use of this HeinOnline PDF indicates your acceptance of HeinOnline's Terms and Conditions of the license agreement available at http://heinonline.org/HOL/License

-- The search text of this PDF is generated from uncorrected OCR text.

-- To obtain permission to use this article beyond the scope of your HeinOnline license, please use:

\section{Copyright Information}




\title{
No-Drop Prosecution of Domestic Violence: Just Good Policy, or Equal Protection Mandate?
}

\author{
Kalyani Robbins*
}

\author{
Last night I heard the screaming \\ Loud voices behind the wall \\ Another sleepless night for me \\ It won't do no good to call \\ The police \\ Always come late \\ If they come at all \\ And when they arrive \\ They say they can't interfere \\ With domestic affairs \\ Between a man and his wife \\ And as they walk out the door \\ The tears well up in her eyes \\ Last night I heard the screaming \\ Then a silence that chilled my soul \\ I prayed that I was dreaming \\ When I saw the ambulance in the road \\ And the policeman said \\ "I' $m$ here to keep the peace \\ Will the crowd disperse \\ I think we all could use some sleep"1
}

Domestic violence is a problem that must be dealt with for what it is: a criminal act. The only way to effectively diminish it is through the full force

* J.D., Stanford Law School, 1999; B.A., University of California at Berkeley, 1995. Articles Editor, Volume 51, Stanford Law Review. Associate at McCutchen, Doyle, Brown \& Enersen in San Francisco. Law Clerk to the Honorable Norman H. Stahl, United States Court of Appeals for the First Circuit, 2000-2001. I wish to thank Sarah M. Buel, University of Texas School of Law Clinical Professor and Co-Director of the University of Texas Domestic Violence Clinic, for her generous feedback on an earlier draft, and for sharing her thoughts regarding some of the issues that arose in this piece. Her input strengthened the piece-its remaining weaknesses are mine alone.

1. TRACY CHAPMAN, Behind the Wall, on TRACY CHAPMAN (Copyright 1983 SBK April Music Inc./Purple Rabbit Music). 
of the criminal justice system, ${ }^{2}$ which must treat domestic violence the same as it treats crime by strangers. The purpose of this note is to argue that aggressive prosecution of domestic violence-at least to the same extent that other violent crimes are prosecuted-is mandated by the Equal Protection Clause of the Fourteenth Amendment. 3 Part I will examine the extent of the problems that pervade the criminal justice system, both historically and in contemporary dealings with domestic abuse. In Part II, I will explain the "no-drop policy," discuss its effectiveness and importance, address the arguments against it, and make some practical suggestions for its implementation. Part III will review the equal protection standards already extended to police protection in domestic violence cases in many jurisdictions. This protection, however, has yet to be extended to the prosecutorial stage, which limits its effectiveness. Consequently, in Part IV I will argue that the equal protection requirement that domestic violence victims receive the same police protection as victims of other crimes should be extended to the courtroom. Effective prosecution of these crimes, which is rare without a no-drop policy, is essential to providing the required equal police protection to domestic violence victims, and should therefore be mandated by the Constitution.

\section{THE LEGAL SYSTEM’S INADEQUATE RESPONSE}

\section{A. Privacy Is Not Worth It}

[I]t is an overgenerous assumption that the wife who has been beaten, poisoned or deserted is still on such terms of delicate good feeling with her spouse that her testimony must not be enforced lest the iridescent halo of peace be dispelled by the breath of disparaging testimony. And if there were, conceivably, any such peace, would it be a peace such as the law could desire to protect? Could it be any other peace than that which the tyrant secures for himself by oppression?4

Marital peace and privacy have traditionally been the reasons asserted for leaving domestic violence alone, or at least for not compelling the victim to testify. Courts and prosecutors distinguish between public and private harm, label domestic violence as the latter, and then often refuse to push it through the legal system if the victim seems reluctant. 5 This can be done through the spousal testimonial privilege, or, in jurisdictions that have usable

2. See Giving Batterers Their Due: Two Vital Bills Aimed at Curbing Domestic Violence Could Get Lost in Shuffle, L.A. TMES, Aug. 27, 1992, at B6 (calling a brush with the law the only thing batterers take seriously, and pointing out the decrease in violence after arrest).

3. U.S. CONST. amend. XIV, $\S 1$.

4. 8 JOHN HENRY WIGMORE, EVIDENCE IN TRIALS AT COMMON LAW § 2239, at 243 (1961).

5. See Malinda L. Seymore, Against the Peace and Dignity of the State: Spousal Violence and Spousal Privilege, 2 TEX. WESLEYAN L. REV. 239, 249-50 (1995) (arguing against the public/private dichotomy). 
exceptions to this privilege and in cases where the couple is not legally married, by simply dropping the case at the victim's request. To do so is to send a message to both the victim and the perpetrator "that domestic violence is a private matter between the two of them and that the state does not care to intervene."6 This creates a situation in which the victim must push the case forward with great effort for it to be prosecuted, as though the attack were a tort rather than a crime. 7 There is a basic assumption at work in the system that "the state should not intervene in domestic matters."8

This attitude ignores the larger social costs of domestic violence, which involve, inter alia, the societal subordination of women. 9 Each time a man hits a woman and gets away with it, all women suffer, both from the risk of harm that has not been prevented, and from the retardation of the movement toward societal equality. Further, society as a whole suffers from violence that leaks into the public on a regular basis at schools, places of employment, and homes of those not otherwise involved. The marketplace of ideas, including those benefiting technology, academia, business, etc., suffers the loss of women who feel confined to their homes or who are otherwise unable to function in the workplace. Perhaps the most important impact of all occurs within the millions of "private" homes across the country. When the law does not govern the private sphere, male dominance and female subordination thrive.10 Put simply, "[a] husband must no longer be allowed to shield himself from legal sanctions for violent crimes by invoking the fact that the crime was committed in the home."11

The law's refusal to interfere with domestic violence is not just practically unsound, but also reflects those societal attitudes toward women ${ }^{12}$ that are most in need of change. Criminal laws establish social norms; they "are the rules by which we define what we stand for as a society."13 By reviewing

6. Malinda L. Seymore, Isn't It a Crime: Feminist Perspectives on Spousal Immunity and Spousal Violence, 90 Nw. U. L. REv. 1032, 1064 (1996). privilege).

7. See Seymore, supra note 5, at 252 (arguing against the marital harmony basis for spousal

8. Amy Eppler, Battered Women and the Equal Protection Clause: Will the Constitution Help Them When the Police Won't?, 95 YALE L.J. 788, 791 (1986).

9. See Cheryl Hanna, No Right To Choose: Mandated Victim Participation in Domestic Violence Prosecutions, 109 HARV. L. REV. 1849, 1877 (1996) (arguing that we should focus on the societal as well as the individual harm of domestic violence).

10. See Seymore, supra note 6, at 1071 (describing traditional feminist critiques of the absence of law from the private sphere).

11. Carolyne R. Hathaway, Gender Based Discrimination in Police Reluctance to Respond to Domestic Assault Complaints, 75 GEO. L.J. 667, 688 (1986).

12. See KAREN DECROW, SEXIST JUSTICE 166 (1974) ("That the court will not enter into the marital abode to set rules is more than a respect for the privacy of citizens. It is also a tacit acknowledgment among male judges, male legislators, and male attorneys (most of whom are husbands) that a husband should not be told how to treat his wife.").

13. Ronald J. Rychlak, Society's Moral Right to Punish: A Further Exploration of the Denunciation Theory of Punishment, 65 TUL. L. REV. 299, 304 (1990). 
the historical treatment of women under law, we can see the context from which this attitude evolved, and how it has been gradually closeted (but not eradicated) with the advent of the women's movement. In early common law, women had no identity separate from their husbands. ${ }^{14}$ Consequently, their interests were assumed to be identical.15 This is why women were deemed incompetent to testify against their husbands under the common law rule that prevented self-interested parties from giving testimony. 16

The practice of wife beating was legally acceptable throughout most of history. In fact, it was not made illegal in every state until 1920.17 In the eighteenth century, William Blackstone codified the right to wife beating in his authoritative commentaries on the common law.18 He stated that because the husband "is to answer for [his wife's] misbehavior, the law thought it reasonable to intrust him with this power of restraining her, by domestic chastisement." 19 Although this tradition is no longer overtly endorsed, the modern law enforcement system is perpetuating Blackstone's notions by passively allowing such "domestic chastisement" to continue, ${ }^{20}$ sometimes to the extent of serious injury. The persistence of these archaic social attitudes and negative stereotypes seriously weakens the impact of modern anti-violence laws, as most police, prosecutors, and courts continue to give domestic violence prosecution low priority. ${ }^{21}$ The vehicle that has been used to transport these old notions to the present-an ideological Trojan horse, if you will-is the doctrine of family privacy. As such, the doctrine must be carefully reconsidered, and possibly rejected as overwhelmingly favoring men over women. 22

14. See Craig R. Isenberg, State v. Taylor: The Louisiana Supreme Court Carves Out an Exception to the Spousal Witness Privilege, 69 TUL. L. REV. 1085, 1085 (1995) (reviewing the history of the spousal testimonial privilege).

15. See id.

16. See id; see also Trammel v. United States, 445 U.S. 40, $43-46$ (1980) (outlining the historical treatment of spousal testimony).

17. See Mary E. Asmus, Tieneke Ritmeester \& Ellen L. Pence, Prosecuting Domestic Abuse Cases in Duluth: Developing Effective Prosecution Strategies From Understanding the Dynamics of Abusive Relationships, 15 HAMLINE L. REV. 115, 116 (1991) (discussing the "[d]eeply rooted ideas" behind the "reluctance of courts to intervene in domestic violence situations").

18. See Daniel P. Whitmore, Enforcing the Equal Protection Clause on Behalf of Domestic Violence Victims: The Impact of Doe v. Calumet City, 45 DEPaul L. REV. 123, 159-60 (1995) (discussing police reluctance to intervene in domestic violence).

19. 1 WILLIAM BLACKSTONE, COMMENTARIES ON THE LAWS OF ENGLAND 444.

20. See Whitmore, supra note 18, at 160-61 (listing the numerous justifications police give for their inaction in domestic violence cases). tions).

21. See Hathaway, supra note 11, at 674-75 (discussing the modern effect of these old no-

22. For more extensive discussion of gender discrimination inherent in the privacy doctrine, see Elizabeth M. Schneider, The Violence of Privacy, 23 CONN. L. REV. 973 (1991). 


\section{B. The Problem is Still Pervasive}

In many jurisdictions today, domestic violence is still not treated as a real crime.23 Very few cases ever reach formal adjudication. ${ }^{24}$ The legal system often fails to adequately respond to the pleas of domestic violence victims until they are seriously injured or killed.25 This failure cuts across all levels of the legal system. This subsection will give examples of how police, prosecutors, judges, and even legislators have demonstrated a willingness to look the other way when it comes to spousal abuse.

\section{Police.}

A Kansas City, Missouri, study of homicides between domestic partners found that in many of the cases, the police had received domestic violence complaints and had been to the victims' homes at least five times before the victim was killed.26 Police often use two different standards for probable cause in assault cases - one for regular assaults, and another, requiring much greater victim injury, for domestic violence cases. ${ }^{27}$

Tracey Thurman's abuse at the hands of her husband continued long after she left him. She made numerous calls to the police asking for help, but received none. After breaking the windshield of Tracey's car while she was inside, in front of a police officer who had idly observed him screaming threats at her, Charles Thurman was convicted of breach of peace and granted a suspended sentence. Tracey later filed a complaint that Charles had threatened to shoot her, but the officer would not issue an order for

23. See Seymore, supra note 5, at 278 (arguing that refusal to arrest and prosecute domestic abusers effectively decriminalizes domestic abuse, and recommending that this approach be changed).

24. One study found that "[t]he wives asked police officers to arrest their husbands in $82 \%$ of the incidents, but an arrest occurred in only $14 \%$ of the incidents." Lee H. Bowker, Police Services to Battered Women: Bad or Not So Bad?, 9 CRIM. JUST. \& BEHAV. 476, 485-86 (1982). When there is an arrest, $60 \%$ to $80 \%$ of domestic violence cases are dropped. See EVE S. BUZAWA \& CARL G. Buzaiva, DOMESTIC VIOlENCE: THE CRIMINAL Justice ReSPONSE 58 (1990). By comparison, only $25 \%$ of felony charges were dismissed in the seventy-five largest counties in 1994. See BUREAU OF JUSTICE STATISTICS, U.S. DEP'T OF JUSTICE, SOURCEBOOK OF CRIMINAL JUSTICE STATISTICS 437 tbl.5.70 (1997). When considering that domestic violence represents a high proportion of all crime, the first figure seems likely to represent a particularly sizable portion of the $25 \%$ in the latter figure.

25. See Hathaway, supra note 11, at 672 (discussing the law enforcement system's reluctance to confront the issue of domestic violence).

26. See Katherine M. Culliton, Finding a Mechanism to Enforce Women's Right to State Protection from Domestic Violence in the Americas, 34 HARV. INT'L L.J. 507, 521 n.63 (1993) (citing S. Rep. No. 102-197, at 34-37 (1991)).

27. See LiSA G. LERMAN, PROSECUTION OF SPOUSE ABUSE: INNOVATIONS IN CRIMINAL JUSTICE RESPONSE 25 (1981) (available from the Center for Women Policy Studies, Washington, D.C.) ("Injuries which would be grounds for arrest of a stranger assailant are often found insufficient to justify arresting a man who beats his wife or girlfriend."). 
Charles' arrest. One day, Charles showed up at Tracey's residence demanding to speak with her. She did not let him inside, and immediately called the police to report that he was there in violation of his probation. The officer dispatched to the scene failed to arrive for twenty-five minutes. Meanwhile, after about fifteen minutes, Tracey went outside to speak to Charles, and he began to repeatedly stab her in the chest, neck, and throat, which he was still doing when the officer arrived. Then, in front of the officer, he dropped the knife, kicked Tracey in the head, ran inside to grab their son, brought him out, threw him on top of his bloodied mother, and continued to pace and threaten her. He was not arrested until Tracey was on a stretcher, and even then he continued to threaten her. ${ }^{28}$

Ed Watson physically abused his wife, Nancy, until she filed for divorce. A few days before the divorce, he threatened her with a knife, causing her to run next door and call the police. The responding officer told her, "[T]f you ever call the police again, I will see to it that you are arrested and you'll never see those two kids again." Even after Ed beat Nancy with a flashlight to the point of hospitalization, and forced her son to eat his own vomit, the police took a report but refused to arrest him. Eventually, Ed came to the house with a gun and held Nancy and the children hostage for three days. Nancy called the police after he held the gun to her head and threatened to kill both her and himself. The arriving officers made a report, but refused to arrest him or to order him to leave. A month later, when Ed was following her home in his car, Nancy drove by the police station and asked for assistance, which an officer assured her he would give. When she got home, Ed was already there. He locked them all in the house and raped and stabbed her. After a neighbor called the police, the responding officer told Nancy that the whole situation was her fault for marrying Ed. Ed, still not under arrest, committed suicide a few hours later. ${ }^{29}$

After Jena Balistreri was severely beaten by her husband, the responding officers stated that she deserved it, and they did not offer her medical assistance. Later, another officer pressured Jena into agreeing not to press charges against her husband, whom she then divorced. Later that year, after her husband crashed his car into her garage, the police refused to arrest him. When she continued to report further harassment and vandalism, the police "received her complaints with ridicule," and even hung up on her once. When a firebomb was thrown into her house, causing a fire, the police took forty-five minutes to respond to the 911 call. After asking Jena's husband a few quick questions, the police determined that he was not responsible. 
When she complained that this was an inadequate investigation, the police told her that she should either move elsewhere or hire a private detective. ${ }^{30}$

\section{Prosecutors.}

Many prosecutors think that domestic violence is not as important as other crimes; some even believe that the victims are to blame.31 Prosecutors often give the victim control over the case, making her feel responsible for any resulting punishment to the batterer.32 "Some prosecutors discourage victims tacitly by questioning the victim in a manner that conveys blame or disbelief, or by actively outlining the disadvantages of prosecution. A few give victims distorted or incomplete legal information that thwart [sic] them from seeking the state's assistance."33 Finally, and perhaps most commonly, many prosecutors undercharge cases of domestic abuse by filing as misdemeanors crimes which actually constitute felonies. 34

\section{Judges.}

Judges are insensitive to the realities of domestic violence surprisingly often. Numerous cases are dismissed simply because the testifying victim is a minute late, and victims are often asked right in front of the defendant whether they would mind if he were released. ${ }^{35}$ In one case in Georgia, a judge repeatedly dismissed the cases of a particular victim of continued abuse, despite the numerous complaints she had filed with the police.36 Each time the judge dismissed one of her cases, he reportedly "mocked," "humiliated," and "ridiculed" her, and then "led the courtroom in laughter" as she left. ${ }^{37}$ Her husband eventually killed her. ${ }^{38}$

30. Balistreri v. Pacifica Police Dept., 901 F.2d 696, 698 (9th Cir. 1990).

31. See Angela Corsilles, No-Drop Policies in the Prosecution of Domestic Violence Cases: Guarantee to Action or Dangerous Solution?, 63 FORDHAM L. REV. 853, 866-67 (1994) (discussing prosecutorial noncooperation).

32. See id. at 868 .

33. Id. at 869 (citations omitted).

34. See id. (arguing that prosecutors downplay domestic violence crimes); see also, e.g., BUZAWA \& BUZAWA, supra note 24, at 56 (citing a national study that found that a third of all misdemeanor domestic violence charges would have been charged as felonies if committed by a stranger).

35. See Bettina Boxall \& Frederick M. Muir, Prosecutors Taking Harder Line Toward Spouse Abuse Violence: New Legal Techniques Tested. But Critics Say Attacks on Women Are Still Not Taken Seriously Enough., L.A. TMES, July 11, 1994, at A1 (reporting on judges' poor handing of domestic violence cases).

36. See Culliton, supra note 26, at 521 n.64 (citing SUPREME CT. OF GA., REPORT ON GENDER BIAS IN THE JUDICIAL SYSTEM 235 (1991)).

37. Id.

38. See id. 
In State v. Taylor, ${ }^{39}$ the Louisiana Supreme Court reversed a case where the district court had denied the state's motion to compel a victim's testimony, citing the district judge's commentary:

I think if this woman's crazy enough to want to get beat up by her husband to within an inch of her life, and she wants to go back and marry him, that's her business. And I couldn't stop her if she wanted to get up on a ledge and jump off the building, if I wasn't close to her. It's her life. I've seen the pictures. I think she's crazy. But what am I going to do? ${ }^{40}$

While the Louisiana Supreme Court reversed this opinion, it set up only a narrow exception to the spousal privilege, holding that a trial judge may refuse to recognize the privilege when the judge finds that fear, threats, or coercion caused the victim to assert it.41 The irony of this ruling is that "[ $t]$ his 'sensitive analysis' is thus entrusted to a trial judge who recited a panoply of myths concerning wife-beating. A rule resting on a trial court's discretion, when the trial judge is unaware of the dynamics of domestic violence, is unlikely to benefit battered women."42

Unfortunately, even well-meaning judges who are concerned about domestic violence often make the mistake of allowing it to escape the legal system too easily. Cheryl Hanna gives some examples of this in her article, No Right to Choose: Mandated Victim Participation in Domestic Violence Prosecutions, ${ }^{43}$ drawn from her own experiences as a prosecutor. In one case, a battered woman invoked her privilege not to testify against her husband, thinking that he would not beat her again. Ms. Hanna gathered enough evidence to proceed anyway, and was pleased to discover that the case would be tried in front of a judge whom she respected for his concern regarding domestic violence. The judge asked the victim (who was in the courtroom) why she would not testify, and she told him that it was a private matter and that she did not want the state to interfere. At her request, the judge dismissed the case, for which she thanked him profusely. The beatings continued, however, with increased severity, until the victim's life basically fell apart.44 The judge meant well in respecting her wishes, but this is a result that we, as a society, should not tolerate, either for this particular woman, or for women in general. 45

39. 642 So. $2 \mathrm{~d} 160$ (La. 1994).

40. Taylor, 642 So. $2 \mathrm{~d}$ at 162 (quoting from the district court opinion).

41. See id. at 166.

42. Seymore, supra note 6 , at 1061.

43. See Hanna, supra note 9, at 1873-76.

44. For a more detailed account, see id. at 1874-76.

45. It is important to note the distinction between dropping a case simply because the victim asks, as happened here, and dropping the occasional case where it is determined that going forward would place the victim in immediate life-threatening danger. In certain extreme cases, methods other than prosecution may be safest. Such determinations should be made conservatively, how- 


\section{Legislators.}

Of course, legislators have a less direct connection with individual cases, so the horror stories that abound for the other three categories of the legal system discussed above are not as available here. However, while lawmakers are in a position to make the proper enforcement of domestic crimes possible, or even mandatory, they have generally refused to do so effectively. Around two-thirds of all states do not have statutes and procedures to ensure prosecution of domestic violence cases. 46 The spousal testimonial privilege, which can prevent prosecution of domestic violence charges, is an evidence rule established by state legislatures. In State v. Taylor, ${ }^{47}$ the court complained that the dynamics of spousal abuse had been ignored by the evidence rule, forcing the court in the interest of justice to create a narrow exception in cases of coercion or intimidation. Unfortunately, it was outside the court's power to create a broader domestic violence exception to the rule:

The spousal witness privilege ... has been part of Louisiana law for a long time, and it was recently affirmed by the legislature when it was considered and included in the Evidence Code adopted in 1992 without any exception as to victim spouses. As a longstanding and recently affirmed legislative enactment, the court would not be justified in reading into the statute an exception purposely omitted by the legislature, regardless of the court's view as to whether or not such an exception represents better policy. ${ }^{48}$

Those legislatures that have yet to take a strong stance against domestic violence continue to tie the hands of numerous judges and prosecutors who are trying to make a difference. The interplay among all four of the systems discussed in this subsection creates a situation where even the caring are often discouraged from effectively enforcing the law.

\section{The Need To Prosecute}

A common misconception about domestic violence victims is that they are making a choice to stay with their abusers. This is evidenced by the often asked question: "Why does she stay with that man?" Perhaps more dangerous, it is also evidenced by the arguments put forth by some feminists ${ }^{49}$ for granting women a choice in whether to prosecute their abusers. There are numerous reasons why women stay with their abusers or are reluctant to

ever, and only by domestic violence experts working in conjunction with prosecutors within a regime where no-drop is the norm, and such a case is the exception.

46. See Culliton, supra note 26, at 537 (arguing that U.S. law is so bad for victims of domestic violence that they should turn to international human rights courts to intervene).

47. 642 So.2d at 166 .

48. Id.

49. Because it is such a difficult and controversial issue, feminists are split as to whether nodrop prosecution is the best method for dealing with the domestic violence epidemic. See Seymore, supra note 6, at 1066-79 (discussing feminist theory and domestic violence). 
prosecute, and rarely do the reasons involve a "choice" to allow their unfortunate circumstances to continue, nor do they stem from some special understanding of how to best deal with their mates.

First, many of these women feel personally responsible for the circumstances because they see it as their role to maintain a peaceful household. 50 Second, the cycle of violence involves three phases: tension building, acute battering, and loving contrition. 51 The last phase makes it much more difficult to leave.52 Third, some battered women may suffer from learned helplessness, which means that their earlier failed attempts to get away have taught them that there is nothing they can do, which discourages further attempts to escape.53 Fourth, if the woman is financially dependent on the batterer, it can be next to impossible to leave, especially if they have children. ${ }^{5}$ Fifth, many victims fear retaliation from the batterer if they try to leave or prosecute. 55 They are wise to have this concern, too, as it is merited by the statistics. As Congressman Jim McDermott stated:

Battered women often face the greatest danger when they do try to leave. Some research indicates that women who leave are at a 75 percent greater risk of being killed by their batterer than those who stay. Think about that for a moment:

Women who leave must face the prospect of being killed.56

Finally, the power dynamic involved is quite difficult for people who have never been in such a relationship to understand. The batterer has the "power, gradually established through use of violence and intimidation, to coerce his victim to shield him from police and court intervention." 57

Incarceration may be the only effective way to relieve the viction of the batterer's control, as it at least incapacitates him for a while.58 In fact, stud-

50. See Seymore, supra note 6, at 1041 (profiling the battered woman).

51. See id. at 1038 (discussing the cycle of violence). See also LENORE E. WALKER, THE BATTERED WOMAN 55-66 (1979); Kathleen Waits, The Criminal Justice System's Response to Battering: Understanding the Problem, Forging the Solutions, 60 WASH. L. REV. 267, 291-97 (1985).

52. See Seymore, supra note 6, at 1043-44.

53. See id. at 1042. The phenomenon of learned helplessness was first discovered by Martin Seligman through tests with dogs. He gave one set of dogs electric shocks that were inescapable, and no shocks to another set. He then gave both sets of dogs shocks that were escapable. Only those dogs that had not previously received the inescapable shocks managed to escape. The others barely even tried, although they were suffering the same pain. See MARTIN E.P. SELIGMAN, HELPLESSNESS: ON DEPRESSION, DEVELOPMENT, AND DEATH 21-25 (1975).

54. See Seymore, supra note 6, at 1043; see also Corsilles, supra note 31 , at 871 ("[W] the woman has no income independent of the batterer, the decision to continue prosecution may result in destitution for the entire family.").

55. It is important to note that this fear is greatly reduced when the victim herself does not control the case, as she is less likely to be blamed for any resulting punishment.

56. 137 CONG. REC. H8782 (1991) (statement of Rep. McDermott) [hereinafter HouSE RECORD].

57. Asmus et al., supra note 17, at 122.

58. See Hanna, supra note 9, at 1887-88 (discussing the effect of incarceration). 
ies have shown that arrest and prosecution of abusers, in sharp contrast to women trying to leave on their own, greatly reduce the likelihood of future harm. 59 Former Kern County District Attorney Ed Jaegels, one of the first prosecutors in California to get tough on domestic violence, called his firm prosecutorial approach "murder prevention."60 Similarly, in San Diego, which is one of a handful of pilot cities for no-drop prosecution of domestic violence, Assistant City Attorney Casey Gwinn commented that "[t]he reality is there are a little more than 100 women alive in San Diego today because of our prosecution effort."61

Finally, while helpful to alleviate some of the pressures victims face, extralegal support systems, on their own, are not the answer. Some advocates argue that we should listen to the women's individual concerns through counseling programs before we impose legal sanctions on their batterers.62 They say that jailing the abusers is bad because "[t]hey just come out more angry,"63 or "[t]here simply isn't enough jail space for all the batterers."64 The problem with this position is that "it's viewing domestic violence as less than a regular crime," argues Deputy Los Angeles City Attorney Alana Bowman, who thinks that batterers should be prosecuted rather than allowed into diversion programs. ${ }^{65}$ These advocates often treat the battering as just one part of a larger control framework to be treated with therapy, which ignores the criminality of the behavior.66 Moreover, these methods have been proven ineffective for deterring future violence. A study conducted by the National Institute of Justice found that the advice/mediation approach left a victim twice as likely to be beaten again than did arrest of the perpetrator. ${ }^{67}$ This is not to say that these programs are not important, as they have made a

59. See Corsilles, supra note 31 , at 877; see also Lawrence W. Sherman \& Richard A. Berk, The Minneapolis Domestic Violence Experiment, 1 POLICE FOUND. REP. 1, 1 (1984) ("[A]rrest was the most effective of three standard methods police use to reduce domestic violence. The other police methods-attempting to counsel both parties or sending assailants away from home for several hours-were found to be considerably less effective in deterring future violence . ...").

60. See Boxall \& Muir, supra note 35, at A1.

61. Mark Hansen, New Strategy in Battering Cases: About a Third of Jurisdictions Prosecute Even without Victim's Testimony, 81 A.B.A. J., Aug. 1995, at 14.

62. See Hanna, supra note 9, at 1863 (discussing the "soft no-drop policies" in effect in most no-drop jurisdictions, where prosecutors work closely with such victim advocates and do not always actually prosecute).

63. Boxall \& Muir, supra note 35, at A1 (quoting Jo Ann Nunez, program coordinator for San Bernardino's domestic violence unit).

64. Id. (quoting Lawrence W. Sherman, University of Maryland Criminology Professor).

65. Id.

66. See Hanna, supra note 9, at 1883 (listing the drawbacks of focusing on the power dynamics of battering).

67. See Arrest Deters Domestic Violence, TrIAL, Aug. 1984, at 83; Phillip M. Boffrey, Domestic Violence: Study Favors Arrest, N.Y. TMES, Apr. 5, 1983, at C1. 
difference in many lives. ${ }^{68}$ However, they must not replace the imposition of criminal sanctions. While legal intervention is not a panacea for domestic violence, it is an indispensable part of the effort to mitigate the problem.

\section{A No-Drop POLICY Is the BEST SOLUTION}

It is not enough to say that police should arrest more, prosecutors should prosecute more, and judges should sanction more, without providing them all with the tools they need to do so. A no-drop policy is the most effective tool, if actively implemented, to secure a higher conviction rate for batterers.

\section{A. What Is a No-Drop Policy?}

In many jurisdictions, domestic violence cases are routinely dropped at the victim's request, or because the victim refuses to testify.69 A no-drop policy takes this option away from the victim once she has filed formal charges against her abuser.70 Further, it limits the prosecutor's discretion to drop a case unless he or she can demonstrate a clear lack of evidence, whereas previously "victim noncooperation" qualified as sufficient justification. ${ }^{11}$ With a no-drop policy, either the victim must testify 72 or the prosecutor must use other evidence such as 911 tapes, other witnesses, and photographs of the injuries-but either way the case must proceed to trial. Basically, "once the charges are filed, the state, and not the victim, becomes the party." 73 Such a policy "conveys an institutional commitment on the part of the criminal justice system to treat domestic violence as a serious crime."74

A truly effective no-drop policy does, however, leave some room for prosecutorial discretion with regard to decisions affecting victim safety. It is important to remember that the goal is to protect women and save lives. In many cases, it may not be wise to force the victim to testify (especially where other evidence is available), and in a few cases, the prosecution itself may place the woman's life in jeopardy. The key is to make clear the distinction between dropping domestic violence cases because they are less im-

68. See HOUSE RECORD, supra note 56, at H8783 ("For many families trying to escape a life of violence, [support programs] have meant the difference between hope and despair.") (statement of Rep. Slaughter).

69. See Corsilles, supra note 31 , at 857 (discussing the impetus for no-drop policies).

70. See BUZAWA \& BUZAWA, supra note 24 , at 122 (noting that the policy restricis victims from freely dropping charges).

71. See id. ("[T]here are usually strict limitations to prosecutorial discretion to drop charges except for demonstrated failure of evidentiary support.").

72. The victim may be compelled to testify if she is in a jurisdiction where there is an exception to the spousal testimonial privilege for crimes against the spouse.

73. Corsilles, supra note 31 , at 858.

74. Id. at 858-59. 
portant and dropping a rare case to save the victim's life. Still, the policy must present itself to the public (especially abusers) as firm (which, for the most part, it would be). Then, at the advice of consulting domestic violence experts, a truly dangerous case may be discretely directed another way, such as through a batterer intervention program. To be certain, though, this must be the rare exception, not the norm, and the only sufficient justification for dropping prosecution would be victim survival.

\section{B. The Arguments}

The no-drop policy has been the single most effective method for getting domestic violence charges to stick. In jurisdictions without a no-drop policy, between fifty and eighty percent of all domestic violence charges are dropped. 75 In contrast, where no-drop policies are in effect, case attrition ranges from ten to thirty-four percent.76 In San Diego, domestic violencerelated homicides dropped from thirty in 1985 (before the policy was implemented) to seven in 1994 (after). 77 This subpart will discuss why this policy is not merely utilitarian, but actually supportive to victims as well.

\section{Responsibility for going forward.}

If the victim is compelled to testify, the state takes the blame, but if she does so voluntarily, she must answer to her batterer for the decision.78 Many women fear retaliation if they choose to testify, 79 and prosecutors have testified before a Texas Senate Committee that nonspouse (not privileged) victims are usually relieved to discover that they do not have to make this choice.80 Once the victims are relieved of the pressure of this decision, "a variety of counseling programs are used to ensure that the thrust of the nodrop effort is supportive rather than coercive." 81 What is more, many batter-

75. See id. at $854 \mathrm{n} .7$ (citing several studies).

76. See id. at 857 n.22.

77. See Hansen, supra note 61 (citing the San Diego City Attorney's Office). It is important to note that in implementing its new no-drop policy, San Diego had the support of a new domestic violence unit in its police department. The policy's success underscores the value of having all parts of the legal system cooperate to fight domestic violence.

78. See Seymore, supra note 5, at 250-51 (arguing that the spousal privilege itself is bad for marital harmony).

79. See Seymore, supra note 6, at 1078-79 (discussing the results of her own study).

80. See Seymore, supra note 5, at 259 (citing TEXAS SENATE INTERIM COMM. FOR DOMESTIC VIOLENCE, REPORT TO THE 74TH LEGISLATURE 74 (1994)).

81. John Riley, Spouse-Abuse Victim Jailed After No-Drop Policy Invoked, NAT'L L. J., Aug. 22, 1983, at 4 (internal quotations omitted). 
ers even stop harassing their victims about the process once they realize that the victims are not responsible for the case going forward. ${ }^{82}$

\section{Empowering the victims.}

Some people have argued that taking the control away from the victim will stifle her own attempts at individual empowerment.83 However, "victims may be empowered simply by witnessing a place where the batterer's control does not extend." 84 Just watching the men admit what they have done in court and be held publicly accountable for their acts can be empowering. 85 To allow a victim, under her abuser's thumb, to stop short his prosecution is to allow his power and control to extend into the courtroom. ${ }^{86}$ It is unlikely to be empowering to her to discover that his dominion is so vast.

\section{Victim in bad position to be making choice.}

Some advocates argue that we should value a woman's right to make her own decisions. ${ }^{87}$ Aside from the key fact that other crime victims are not usually given this option, giving the domestic violence victims this choice ignores the dynamics of abuse and the fact that defendants often coerce their partners not to prosecute.88 Lenore Walker, who is frequently cited for her insights on domestic violence, has defined the "battered woman" as one "who is repeatedly subjected to any forceful physical or psychological behavior by a man in order to coerce her to do something he wants her to do without any concern for her rights." 89 By making the victim choose, the prosecutor gives the batterer a wedge to use against her, 90 which "virtually

82. See Seymore, supra note 6, at 1079-80 (citing THE GENDER BIAS TASK FORCE OF TEXAS, FINAL REPORT 70-71 (1994)).

83. See, e.g., Developments in the Law: Legal Responses to Domestic Violence, 106 HARV. L. REV. 1498, 1541 (1993) (outlining the drawbacks of no-drop policies).

84. Corsilles, supra note 31 , at 879.

85. See Seymore, supra note 6, at 1078 (concluding this based on interviews with domestic violence victims); see also Angela West, Prosecutorial Activism: Confronting Heterosexism in a Lesbian Battering Case, 15 HARV. WOMEN's L.J. 249, 255-56 (1992) ("I believe that the victim is empowered by seeing the defendant prosecuted. ... Seeing the abuser in a position of social disapproval may be the first step toward realizing that there is help available.").

86. See Corsilles, supra note 31 , at 881 ("By dismissing cases simply because a victim requests it, prosecutors allow batterers to extend their power and control into the courtroom.").

87. See, e.g., Hanna, supra note 9, at $1865-66$ (outlining the argument that a no-drop policy may revictimize or punish the victim).

88. See Seymore, supra note 5, at 251 (arguing against the marital harmony justification for the spousal testimonial privilege).

89. WALKER, supra note 51 , at xv.

90. See Seymore, supra note 5, at 256 ("[T]he court puts the burden on the woman for going through with the charges, which gives the batterer a wedge to use."). 
invites batterers to intimidate victims into withdrawing the charges." 91 The victim is left to be manipulated by her batterer, as well as his attorney.92 Furthermore, even without the abuser's active persuasion, a domestic violence victim has usually been through so much emotional and physical turmoil that she is unable to make the same rational decisions she might make during times when her head is more clear.93 In sum, when we consider the power that batterers have to make their victims act on their behalf, we see the need for legal intervention that takes away some of that control.94

\section{Effect on the batterer's behavior.}

I have already discussed the impact arrest and prosecution have on the likelihood of future violence. In addition, the very existence of a no-drop policy itself can have a strong effect on batterers. First, if the victim cannot control the process, the batterer has less incentive to exert his control over her after the charges are filed.95 Second, prosecutors have observed that batterers are more likely to plead guilty if the case cannot be dismissed.96 Furthermore, after one time through the process, batterers are more acutely aware of the threat of certain prosecution, which can act as an even more effective deterrent than mere arrest.97 A no-drop policy can take a significant bite out of an abuser's maleficent reign.

\section{Unlikely contempt charges.}

Some victim advocates have expressed concern that this policy, combined with an exception to the spousal testimonial privilege for domestic

91. Corsilles, supra note 31 , at 868.

92. See Seymore, supra note 6, at 1064 ("The [spousal privilege] rule leaves the wife to be manipulated by her husband and his attomey into invoking her privilege not to testify.").

93. See State v. Taylor, 642 So. $2 d 160,166$ (La. 1994) ("Fear, self-blame, and other emotional factors often leave a battered spouse unable to make a sound judgment as to whether to testify against an abusive spouse. Exercise of the spousal witness privilege may be the result of coercion, fear, subjugation, or undue influence, perhaps not even consciously recognized by the abused spouse in some circumstances."); Steven Goode \& M. Michael Sharlot, Article V: Privileges, 30 Hous. L. REV. 489, 561-62 (1993) (updated by Cathleen C. Herasimchuk) (citing several studies which found that abused women are hardly ever in the best position to make these decisions). This is not to say that there are not cases in which domestic violence victims correctly believe that their lives are at risk if their batterer is prosecuted. Such cases must be weeded out and dealt with through the aid of victim advocates.

94. See Asmus et al., supra nöte 17, at 149 ("Understanding battering as a system of coercive and abusive behaviors that compels its victim to submit to the abuser and act on his behalf emphasizes the necessity of developing a comprehensive response by the legal system.").

95. See Hanna, supra note 9, at 1865 ("[Pro-prosecution advocates] contend that the batterer has less incentive to try to control or intimidate his victim once he realizes that she no longer controls the process.').

96. See Corsilles, supra note 31 , at 874 (discussing the benefits of no-drop policies).

97. See id. 
violence victims, would lead to contempt charges and jail for the victims, thus revictimizing them. 98 However, unmarried victims have never had the privilege not to testify, and an investigation by the Texas Senate Committee on Domestic Violence found no history of contempt charges against these victims. ${ }^{99}$ Furthermore, even with the stricter combination of no-drop and no privilege, women will be held in contempt only in extremely rare circumstances. It is far more likely that the threat of contempt will persuade the women to testify, 100 or that prosecutors will use other evidence in the event that they refuse to do so and in those situations in which testifying really would endanger the victims' lives. One study found that in jurisdictions with no-drop policies, victims fully cooperated with prosecutors in sixty-five to ninety-five percent of cases. 101 The only circumstance in which contempt is likely is if the victim refuses to testify and there is no other evidence but her testimony. Even then, prosecutors will be reticent to wield the contempt power unless the violence was severe, in which case it may be a good idea to remove the victim from the risk of harm anyway. Indeed, the more enlightened prosecutors now focus on going forward without the victim's testimony whenever possible. Finally, the risk that once in a great while a victim will be incarcerated for contempt is outweighed by the benefit to millions of other women who are made safer by their abuser's prosecution which may not otherwise have taken place. Based on the reduction in domestic homicides in jurisdictions where no-drop policies are already in place, it is reasonable to conclude that significantly more women will escape murder than be jailed.

\section{Victims no less likely to call police.}

Another major concern many battered women's advocates have expressed is that if prosecution is certain, and victims will have no control over the process, they will be less likely to call the police in the first place, thus placing them in greater immediate risk during the beatings. 102 However, the actual results in jurisdictions with no-drop policies do not support this fear.

98. See Riley, supra note 81 ("If the goal is to hold the accused accountable, then it's simply not the logical extension to jail the victim instead of the abuser.") (quoting attorney Lisa Lehrman).

99. See Seymore, supra note 5, at 258-59 ("[T]he Committee reported that no ... contempt charges have resulted against unmarried victims where no privilege existed.").

100. See Hanna, supra note 9, at 1892 ("In most cases, such extreme sanctions will probably not be necessary. Once the existence of a mandated participation policy is common knowledge, women will be much more likely to cooperate."); Sam Howe Verhovek, Athlete and Legal Issue on Trial, N.Y. TMES, Feb. 19, 1996, at A8 ("Prosecutors in Texas and elsewhere say that while the threat behind the law is an effective means of persuading a battering victim to testify, it has extremely rarely resulted in a case where such a person has been jailed for refusing to testify.").

101. See Corsilles, supra note 31, at 873 (citing Maureen McLeod, Victim Noncooperation in the Prosecution of Domestic Assault, 21 CRIMINOLOGY 395, 401 (1983)).

102. See Hanna, supra note 9, at 1865 ("These advocates are ... concerned that if arrest leads to automatic prosecution, women will be less likely to call the police for help or protection."). 
In California, where a number of counties have implemented pro-prosecution policies, there was a twenty-seven percent increase in domestic violence calls to the police between 1989 and 1993 in response to the increased law enforcement over that period. ${ }^{103}$ This makes sense when you consider the phone call to be an instinctive act of survival rather than a calculated decision based on contemplation of the consequences. If the police are more responsive, which they would be if they knew that prosecution were likely and their efforts were not fruitless, women are more likely to turn to them in their time of need.104 Besides, it is often people other than the victim (neighbors, children, etc.) who make the call to 911.105

\section{The Spousal Testimonial Privilege Exception}

It would be less effective to implement a no-drop policy without a wellwritten domestic violence exception to the spousal testimonial privilege, ${ }^{106}$ as the policy would be painfully ineffective. If women can assert the privilege, even in a no-drop jurisdiction, many of the problems discussed earlier in this note would remain in effect. Regardless of whether they support a no-drop policy (some may wish to hold on to prosecutorial discretion), many prosecutors "hail the removal of spousal immunity in [domestic violence] cases as an important tool to secure convictions ...."107 In a survey of battered women in shelters, almost every one of them opined that the privilege exception was a good idea, stating that they would not testify if given the choice, but would tell the truth if compelled to testify. ${ }_{108}$ Essentially, this evidence rule can sometimes make the difference between a strong case and a dropped case. 109 The availability of the spousal privilege has contributed to

103. See Boxall \& Muir, supra note 35, at A1 (citing to state Department of Justice figures).

104. See Hanna, supra note 9, at 1897 ("[P]eople call the police because they are in crisis and need protection.").

105. See id. ("[N]eighbors, children, or other people in the household, rather than the victim herself, often initiate the 911 call.").

106. The spousal testimonial privilege at issue in this note is that which makes a spouse incompetent to, or allows a spouse to refuse to, testify against his or her spouse during their marriage. This applies to any type of negative testimony, and is only in force while the two are married. This note does not address the marital confidential privilege, which prevents, against his or her will, a person from testifying ever, even after the marriage is over, regarding statements of his or her spouse or former spouse that were made in confidence during the marriage. See GraHAM C. LILLY, AN INTRODUCTION TO THE LAW OF EVIDENCE §§ 9.3, 9.4 (2d ed. 1987) (discussing the common law marital privileges).

107. Verhovek, supra note 100, at A8.

108. See Seymore, supra note 6, at 1076-79 (describing a survey conducted by Seymore's research assistant, Marina Mata-de la Garza).

109. See Seymore, supra note 5, at 257-58 (explaining that many prosecutors, even in no-drop jurisdictions, are forced to drop charges because it is so difficult to bring a strong case when the victim asserts the privilege). 
the overall reluctance among prosecutors to bring these charges in the first place. 110

Not only is it important to have an exception to the spousal testimonial privilege for victims of domestic violence, but also it is essential that the exception be written properly to encompass all possibilities. The need for better written evidence rules is demonstrated by the number of cases arising in which spousal privilege was asserted despite the spouse victim exception. For example, a common charge police use in cases of domestic violence is "disorderly conduct," which is defined as a crime against the community rather than a crime against the spouse. As a result of this, victims have been found incompetent to testify against their husbands under evidence rules with narrow privilege exceptions for crimes against the spouse.111 I recommend an exception to the spousal privilege which reads:

There is no privilege under this rule (1) in proceedings in which one spouse is charged with a crime against the person or property of the other or of a child of either, or with a crime against the person or property of a third person committed in the course of committing a crime against the other, [or with a crime against the community that resulted in any harm to the person or property of the other or to a child of either,] or (2) as to matters occurring prior to the marriage....112

\section{Nontestimonial Evidence}

Finally, it is important under a no-drop policy (or anywhere, for that matter) for prosecutors to obtain as much nontestimonial evidence as they can rather than rely on the victim's testimony entirely, as many do now. This is done in homicide cases all the time, because the victim is deceased, and the conviction rate is high in such cases. The use of nontestimonial evidence will reduce the likelihood that the victim will have to take the stand, 113 which is always good, but it is especially helpful when she is reluctant. Using other evidence also treats the crime as a matter of public concern, meriting the use of investigative resources, rather than a tort with the victim as the plaintiff.

Using a variety of evidentiary sources is much more effective than presenting victim testimony alone, even when the victim cooperates fully. "In

110. See Seymore, supra note 6, at 1033 (trying to explain the reluctance of police and prosecutors to deal with domestic violence).

111. See, e.g., City of Huron v. Bass, No. E-90-29, 1991 WL 137009, at *2-3 (Ohio Ct. App. July 26, 1991) (unpublished opinion).

112. The unbracketed portion is quoted from the Supreme Court's recommended Rule 505, which was not enacted by Congress, see FED. R. EVID. 505, but many states have adopted similar language. See, e.g., CAL. EVID. CODE $\S 972(\mathrm{e})(1)$, (2). The bracketed portion is mine.

113. See Hanna, supra note 9, at 1857 ("A proper investigation can reduce the likelihood that the victim will ever have to take the stand."). 
the courtroom, judges and juries simply do not always listen to or understand what women have to say." 114 If their stories are supplemented with extrinsic evidence, it lends them credibility in circumstances where they desperately need it. In addition, the victims themselves often tone down the story in their testimony, either because they underestimate the seriousness of the crime, or because they want to protect their abuser or avoid antagonizing him further.115 Kern County District Attorney Ed Jaegels commented, "[i]n terms of getting convictions, it's clear that [using 911 tapes, photographs of injuries, and police reports to prove the case] works well."116 In fact, in cases in which there was a careful investigation upon the victim's initial complaint, prosecutors have been able to secure convictions despite adverse testimony from the victim that she had not been harmed. ${ }^{117}$

Finally, prosecutors are more likely to make an effort to put together a solid case if they are in a no-drop jurisdiction, as they may no longer drop a case with a cursory stamp of "victim noncooperation."118 Also, police are likely to respond to the prosecutors' needs with stronger on-scene investigations. ${ }^{119}$ Likewise, "[a]s judges become conditioned to trying cases without the victim and admitting certain types of evidence under newly-argued exceptions to hearsay rules, cases become much easier to prove."120 Basically, under a no-drop policy, the whole system works together more effectively.

\section{POOR POLICE RESPONSE TO DOMESTIC VIOLENCE VIOLATES EQUAL PROTECTION}

Although the Supreme Court has yet to rule on this exact point, many scholars argue and lower courts often hold that the police may not respond differently to domestic violence than to stranger assaults. While there is no affirmative constitutional requirement that the state protect its citizens from crime, ${ }^{121}$ the state may not discriminate in its provision of police protec-

114. Id. at 1899.

115. See id. at 1900 ("[V]ictims of domestic violence often understate the situation, try to protect the batterer, or blame themselves for the violence.").

116. Boxall \& Muir, supra note 35, at A1.

117. See, e.g., Hansen, supra note 61 , at 14 (describing a case in which a man was convicted of assaulting his girlfriend despite her testimony that he had not hit her).

118. See Corsilles, supra note 31 , at 874 ("Prosecutors, who can no longer cite 'victim noncooperation' as a legitimate reason to dismiss a case, have learned to prosecute cases without the benefit of victim testimony.").

119. See id. at 877.

120. $I d$.

121. See Balistreri v. Pacifica Police Dep't, 901 F.2d 696, 699-700 (9th Cir. 1990) ('There is, in general, no constitutional duty of state officials to protect members of the public at large from crime.") (citing Martinez v. California, 444 U.S. 277, 284-85 (1980)). 
tion.122 If an officer fails to provide fair and equal protection of the laws, he may be held liable for any resulting harm under 42 U.S.C. $\S 1983.123$ This duty to protect equally applies not only to written police policies, but to the equal enforcement of otherwise neutral policies as well.124 The United States District Court for the District of Connecticut has applied this doctrine to a police "practice of affording inadequate protection, or no protection at all, to women who have complained of having been abused by their husbands or others with whom they have had close relations," calling it "tantamount to an administrative classification used to implement the law in a discriminatory fashion."125

In dealing with cases of unequal administration of neutral laws, adverse impact on a particular class is not enough to create a constitutional violation. It is also necessary to show intent to discriminate against that class.126 The discriminatory purpose need not be the sole impetus for the action; it need only be a motivating factor.127 One step toward demonstrating discriminatory purpose is to make a showing that the police have a policy or custom of providing less protection to victims of domestic violence than to other assault victims. ${ }^{28}$ In order to establish the existence of such a policy, plaintiffs usually provide evidence of a "pattern or practice" of discrimination.129 Plaintiffs may utilize statistical evidence to demonstrate that the discriminatory practice is so pervasive as to suggest intent. 130 In many jurisdictions, there

122. See Watson v. City of Kansas City, 857 F.2d 690, 694 (10th Cir. 1988) ("Although there is no general constitutional right to police protection, the state may not discriminate in providing such protection.").

123. See Smith v. Ross, 482 F.2d 33, 36-37 (6th Cir. 1973) ("A law enforcement officer can be liable under $\S 1983$ when by his inaction he fails to perform a statutorily imposed duty to enforce the laws equally and fairly, and thereby denies equal protection ....").

124. See Yick Wo v. Hopkins, 118 U.S. 356, 373-74 (1886) (invalidating facially neutral laws applied with an "unequal hand"); see also Arlington Heights v. Metropolitan Hous. Dev. Corp., 429 U.S. 252, 266 (1977) ("Sometimes a clear pattern ... emerges from the effect of the state action even when the governing legislation appears neutral on its face."); Hoots v. Pennsylvania., 672 F.2d 1107,1114 (3d Cir. 1982) (holding that when official action affects one race or class differently from another, discriminatory intent can be inferred).

125. Thurman v. City of Torrington, 595 F. Supp. 1521, 1527 (D. Conn. 1984).

126. See Washington v. Davis, 426 U.S. 229, 245 (1976) (rejecting an equal protection claim based on disparate impact alone). 229).

127. See Arlington Heights, 429 U.S. at $265-66$ (construing Washington v. Davis, 426 U.S. at

128. See Watson v. City of Kansas City, 857 F.2d 690, 694 (10th Cir. 1988) ("[T]o survive summary judgment, the plaintiff must go beyond her pleadings and show that she has evidence of specific facts that demonstrate that it is the policy or custom of the defendants to provide less police protection to victims of domestic assault than to other assault victims.").

129. See Lauren L. McFarlane, Domestic Violence Victims v. Municipalities: Who Pays When the Police Will Not Respond?, 41 CASE W. RES. L. REV. 929, 936 (1991) (discussing methods of demonstrating an informal policy of police nomprotection of domestic violence). tistics).

130. See, e.g., Watson, 857 F.2d at 690 (finding for the plaintiff partially on the basis of sta- 
will be strong statistical evidence of less police protection for domestic violence. 131

Intent may also be inferred from stereotype-derived remarks made by police officers in the course of responding to domestic violence calls. ${ }^{132}$ The Ninth Circuit has held that disrespectful remarks police made to domestic violence victims, such as a statement that they "did not blame plaintiff"s husband for hitting her, because of the way she was 'carrying on,' ... strongly suggest an intention to treat domestic abuse cases less seriously than other assaults, as well as an animus against abused women."133 Some judges have argued against this interpretation, noting that the Constitution does not protect people from politically incorrect remarks, nor does it require police officers to speak tactfully to crime victims. ${ }^{134}$ The primary problem with this argument is that the plaintiffs in equal police protection cases are not suing for these remarks or their hurtful effect on the psyche. They are using them as evidence to show discriminatory intent that resulted in harm that is in violation of the Constitution. This distinction is key.

\section{A. The Gender Argument}

Some proponents of treating police protection from domestic violence as an equal protection issue argue that the classification is gender-based. While it is true that victims of domestic violence are nearly always women, 135 this argument can be difficult to make. However, if a plaintiff is able to convince a judge that the police treatment she received was based on her gender, the judge will use an intermediate scrutiny standard of review, which would place the burden on the defendants to show an important government interest in the classification. 136 In domestic violence cases, showing an important government interest in disparate handling of violent crimes would be unlikely. Winning the equal protection case would therefore only require a showing that the classification is gender-based, and that the class was treated differently for that reason. Hence, this subsection will focus only on the issue of whether domestic violence classifications are gender-based.

In order to demonstrate that a classification that is not facially genderbased but has an adverse impact on women is worthy of intermediate scru-

131. See notes 23-30 supra and accompanying text.

132. Cf. Price Waterhouse v. Hopkins, 490 U.S. 228, 251 (1989) (holding that "stereotyped remarks can certainly be evidence that gender played a part" in employment decisions).

133. Balistreri v. Pacifica Police Dep't, 901 F.2d at 696, 701 (9th Cir. 1990).

134. See, e.g., Doe v. Calumet City, 641 N.E.2d 498, 514 (Ill. 1994) (Heiple J. \& Bilandic, J., dissenting).

135. See Hathaway, supra note 11, at 671 n.20 (citing U.S. Department of Justice figures).

136. See Craig v. Boren, 429 U.S. 190, 197 (1976) ("To withstand constitutional challenge. . . classifications by gender must serve important governmental objectives and must be substantially related to achievement of those objectives."). 
tiny, a plaintiff must survive the strict test set up in Personnel Administrator of Massachusetts v. Feeney.137 Under this two-prong test, a court will first make sure that the "classification is indeed neutral in the sense that it is not [covertly] gender based." 138 If the classification is found to be gender-based, the court will scrutinize it accordingly. If not, the court will determine "whether the adverse effect reflects invidious gender-based discrimination."139

A classification may be considered covertly gender-based if its disparate "impact ... could not be plausibly explained on a neutral ground." 140 In Feeney, the state gave a hiring preference to veterans to reward them for their service. ${ }^{141}$ The Court found the this to be a neutral goal even though ninety-eight percent of these veterans were men, in part because the disadvantaged class, nonveterans, was nearly equally male and female.142 Domestic violence is distinguishable from this because the preferred class, abusers, is nearly all male, and the disadvantaged class, victims, is nearly all female. Furthermore, the most plausible explanation for a policy that favors leaving the abusers alone is primarily based on stereotypical notions of male rule over the household and female subordination to her partner. ${ }^{143}$ These "traditional" gender roles are not an acceptable justification for a classification. Consequently, the disparate treatment could be found to be covertly gender-based, which is all that Feeney requires to get to intermediate scrutiny.

Assuming, arguendo, that the classification is not covertly gender-based, it could still fail the second prong of the Feeney test because it "reflects invidious gender-based discrimination,"144 which is determined according to its underlying purpose.145 A classification has such an invidious purpose if "the decisionmaker ... selected or reaffirmed a particular course of action at least in part 'because of,' not merely 'in spite of,' its adverse effect upon an identifiable group." 146 As discussed earlier, discrimination against victims of domestic violence is often based on the stereotypic belief in the subordinate role women should play in a relationship. The police practice of tolerating such violence stems from a time when it was condoned in order to keep

137. 442 U.S. 256 (1979).

138. Id. at 274.

139. Id.

140. Id. at 275.

141. See id.

142. See id.

143. See notes 4-22 supra and accompanying text for a discussion of the historical background behind the treatment of domestic violence.

144. Feeney, 442 U.S. at 274.

145. See id. at 275.

146. Id. at 279. 
women in this role. As such, the disparate treatment of domestic violence victims took effect "at least in part because of" its adverse effect on women.

Further, the Supreme Court has clearly declared unconstitutional those classifications which are based on, or tend to perpetuate, "archaic and overbroad generalizations" about women.147 Mississippi University for Women $v$. Hogan, ${ }^{148}$ for example, held that excluding men from a nursing school "tend[ed] to perpetuate the stereotyped view of nursing as an exclusively woman's job."149 The Supreme Court held that the discriminatory intent need not be conscious, but may be based on "the mechanical application of traditional, often inaccurate, assumptions about the proper roles of men and women." 150 It is likely that a police policy of "smoothing over" domestic disputes where the male was over-disciplining his partner as he would be expected to do in past centuries, rather than arresting him for his criminal attack, is based on such assumptions.

\section{B. Treating "Domestic Violence Victims" as a Class}

In spite of the arguments in the previous section, it is much simpler to skip the gender basis argument and focus on the classification of domestic assaults versus other assaults. Although the scrutiny standard is more deferential, 151 this method of proving an equal protection violation can prove less difficult on the whole. This is because it is easier to prove that there is no legitimate reason for treating domestic violence victims differently than it is to prove that the classification of domestic violence is gender-based. ${ }^{152}$ This is not to say that the latter is impossible. As discussed above, there are some reasonable arguments. It is simply that, as there is no justification for the distinction, the effort to obtain the higher level of scrutiny is not necessary. In Bartalone v. County of Berrien, ${ }^{153}$ which dealt with the classification of domestic violence victims, a United States district court held that "[p]olice officials cannot refuse to protect a particular class of persons, when under the same or similar circumstances they would protect others, without a rational

147. Craig v. Boren, 429 U.S. 190, 198 (1976) (citations omitted) (striking down an Oklahoma law providing a different drinking age for men and women).

148. 458 U.S. 718 (1982) (invalidating the exclusion of men from a state nursing school).

149. Id. at 729 .

150. Id. at 726 .

151. A seemingly arbitrary classification that is not based on a suspect class is subject to "rational relationship" scrutiny, which requires the defendant to articulate a legitimate reason for the disparate treatment. See City of Cleburne v. Cleburne Living Center, Inc., 473 U.S. 432, 440-42 (1985).

152. See, e.g., Watson v. City of Kansas City, 857 F.2d 690, 696-97 (10th Cir. 1988) (holding that sufficient evidence had been presented for a jury to find that domestic violence victims were provided with less police protection than others).

153. 643 F. Supp. 574 (W.D. Mich. 1986). 
reason for doing so."154 Despite this deferential level of scrutiny, the defendants in that case, like those in several other cases discussed below, were unable to offer any justification at all for failing to protect the plaintiff from her husband. ${ }^{155}$

In her note, Domestic Violence Victims v. Municipalities: Who Pays When the Police Will Not Respond?,156 Lauren L. McFarlane argues that a slightly different level of scrutiny should be, and often is, applied to the domestic violence classification than to other arbitrary classifications. 157 She points out that the "courts have not been entirely deferential in examining the rationality of policies of discrimination against victims of domestic violence."158 While the "rational basis" test usually results in automatic approval of any justification, this has not been the case with domestic violence failure-to-protect cases. $159 \mathrm{McF}$ arlane explains:

A court that suspects irrational negative stereotypes about a group underlie the adoption of a discriminatory policy may be justified in applying a rational basis standard that is nondeferential. In this situation, courts look carefully at the means and ends of the policy, even when no suspect class is involved and the level of scrutiny is theoretically minimal. 160

McFarlane analogizes this to City of Cleburne v. Cleburne Living Center, Inc., ${ }^{161}$ which applied a nondeferential rational basis standard of review to a city policy found to be based on "irrational fears about mentally retarded persons ...."162 The Court stated that "[p]rivate biases may be outside the reach of the law, but the law cannot, directly or indirectly, give them effect."163 Because "[d]omestic violence victims are not situated differently from other citizens in their need for protection from violence," and because "'mere negative attitudes' about victims of abuse lie behind the police refusal to intervene in domestic assaults," McFarlane urges that the Cleburne nondeferential rational basis standard be applied.164

\section{Court Holdings}

While the Supreme Court has yet to make it official, many courts in domestic violence failure-to-protect cases have held that there was an equal

154. Id. at 577 .

155. Id.

156. McFarlane, supra note 129.

157. See id. at 949-52.

158. Id. at 942 .

159. See id. at $949-50$.

160. Id. at 950.

161. 473 U.S. 432 (1985).

162. McFarlane, supra note 129 , at 950 .

163. Cleburne, 473 U.S. at 448 (quoting Palmore v. Sidoti, 466 U.S. 429,433 (1984)).

164. McFarlane, supra note 129, at 951 (quoting Cleburne). 
protection violation, or at least that the plaintiff had stated a claim upon which relief could be granted.165 Of all the methods plaintiffs have used to sue the police for poor response to calls of domestic abuse, equal protection claims have been the most successful. ${ }^{166}$ The Sixth, ${ }^{167}$ Ninth, 168 and Tenth ${ }^{169}$ Circuits, and the Districts of Connecticut, 170 Eastern Pennsylvania,171 and Western Michigan, ${ }^{172}$ as well as the Supreme Court of Illinois, ${ }^{173}$ have all held to some extent that treating domestic violence differently from other crime violates, or may violate, the constitutional requirement of equal protection of the laws.

It is not entirely surprising that the Supreme Court has yet to resolve this issue. Because the lower courts are holding for the plaintiffs, they have no reason to appeal to the Supreme Court, and although the defendants keep losing these cases, it is probably not in their interests to appeal to the Supreme Court. If the Court ruled that insufficient response to domestic abuse calls was a constitutional violation, these same defendants would have numerous new lawsuits on their hands. Further, they could possibly be required to improve their practice significantly more than they do with just one lower court holding against them. As such, we must look to the holdings on

165. See notes 164-70 infra.

166. See McFarlane, supra note 129, at 934 ("Suits charging that police department policies have deprived plaintiffs of equal protection of the laws have been the most consistently successful type of domestic violence failure-to-protect claims.").

167. See Perrino v. City of Newton Falls, No. 91-4023, 1992 WL 197328, at *6 (6th Cir. Aug. 14 , 1992) (holding that although the plaintiff "adequately had pleaded a constitutional violation by alleging that the prosecutor's actions were pursuant to an official policy of denying domestic violence victims the equal protection of the law," she had failed to select the correct defendant, and therefore upholding summary judgment against her with some reservation).

168. See Balistreri v. Pacifica Police Dep't, 901 F.2d 696, 701-02 (9th Cir. 1990) (reversing the dismissal of a claim that poor police protection violated equal protection and holding that if the alleged facts were found to be true, relief would be appropriate).

169. See Watson v. City of Kansas City, 857 F.2d 690, 695 (10th Cir. 1988) (reversing summary judgment for the defendants in a claim that a domestic abuse victim's rights to equal protection of the laws were violated when the city failed to provide victims of domestic violence with the same police protection as victims of nondomestic violence).

170. See Thurman v. City of Torrington, 595 F. Supp. 1521, $1528-29$ (D. Conn. 1984) (holding that the plaintiff had properly stated a claim of a violation of the Fourteenth Amendment's Equal Protection Clause when she complained that police officers used an administrative classification that treated assaults differently if they took place in a domestic relationship, and finding that such a policy was based upon the impermissible stereotypic view that it is acceptable for husbands to physically abuse their wives). Later, a jury awarded Thurman \$2.3 million. See Officers Must Pay \$2.3 Million to Wife Maimed by Husband, N.Y. TMMES, June 26, 1985, at B6.

171. Dudosh v. City of Allentown, 722 F. Supp. 1233, 1235-36 (E.D. Pa. 1989) (holding that the plaintiff had established an equal protection claim by asserting that the police responded less to domestic assaults than to nondomestic assaults).

172. See Bartalone v. County of Berrien, 643 F. Supp. 574, 577 (W.D. Mich. 1986) (holding that a complaint alleging that police failed to act on reports of spousal abuse stated an equal protection violation).

173. See Doe v. Calumet City, 641 N.E.2d 498, 509-10 (III. 1994) (holding that the complaint of police nonprotection for domestic violence stated a $\$ 1983$ claim of gender discrimination). 
the appellate level for guidance. Based on these holdings, it appears that the police must provide the same protection for battered women that they do for other assault victims. These rulings just have yet to spread completely across the country.

\section{IMPLEMENTATION OF NO-DROP POLICIES IN ORDER TO PROVIDE BATTERED WOMEN WITH EQUAL PROTECTION OF THE LAWS}

As I mentioned at the start, the purpose of this note is to argue that battered women's equal protection guarantees may depend upon the implementation of no-drop policies. Based on the first three parts of this note, this might be done with a simple syllogism: Equal police protection for domestic violence victims is already constitutionally required; 174 prosecution, the only way to protect battered women to the same extent as other crime victims, occurs less frequently without a no-drop policy;175 therefore, a no-drop policy is an excellent way to ensure the equal protection of the laws. Of course, a well-reasoned argument on such a controversial matter requires more, which is the purpose of this part.

Equal protection law does extend to prosecutors. In Wayte v. United States, the Supreme Court held that "although prosecutorial discretion is broad, it is not 'unfettered. Selectivity in the enforcement of criminal laws is ... subject to constitutional constraints." "176 The Wayte Court held that "[i]n particular, the decision to prosecute may not be 'deliberately based upon an unjustifiable standard such as race, religion, or other arbitrary classification." 177 The judicial standard to be applied to prosecutors is quite simple, and can be dealt with in much the same way as with police protection. "It is appropriate to judge selective prosecution claims according to ordinary equal protection standards. Under our prior cases, these standards require petitioner to show both that the passive enforcement system had a discriminatory effect and that it was motivated by a discriminatory purpose."178

At the prosecutorial level, we should treat domestic violence the same as we treat other crimes if we are to provide the equal protection of the laws. This requires the same mandated participation that is imposed on victims of other crimes. Nonprosecution and underprosecution (as misdemeanors) of domestic violence charges is tantamount to "de facto decriminalization of

174. See notes 121-173 supra and accompanying text.

175. See notes 49-120 supra and accompanying text.

176. Wayte v. United States, 470 U.S. 598, 608 (1985) (quoting United States v. Batchelder, 442 U.S. 114, 125 (1979)) upholding a conviction for failing to register for the draft against an equal protection challenge).

177. Id. (emphasis added) (quoting Oyler v. Boles, 368 U.S. 448, 456 (1962)).

178. Id. (citations omitted). 
domestic abuse,"179 which is clearly unconstitutional. Furthermore, decisions not to prosecute are often based on the very same archaic and stereotypical notions that many police officers hold.

The requisite discriminatory intent is just as easy to establish with regard to the policy of dropping numerous domestic violence charges as it is with poor police response. As discussed earlier, the extreme disparate impact itself may be a starting point for intent. Also, the Supreme Court suggested in Arlington Heights 180 that the historical background of a policy is relevant in determining whether it has a discriminatory purpose. 181 The historical background of nonprosecution of domestic violence charges stems from the doctrine of family privacy. This doctrine both "constitutes respect for the man's authority within the home, [and] disempowers women by refusing to recognize their most basic rights. Given the force of law in battering situations, a reliance on this doctrine of family privacy must be understood as an intent to perpetuate male rule within the home." 182 This historical background should be sufficient to show an intent to harm women, whether conscious or "mechanical,"183 for the sake of an equal protection claim.

The notion of prosecutorial discretion does not change this analysis. Prosecutors do have a right to determine which cases in general are worth prosecuting, based on severity and likelihood of conviction. ${ }^{184}$ Care must be taken, however, that they do not make these choices for the wrong reasons. In Watson, 185 the defendant police argued that in many of the cases of nonarrest, the police on duty had not found probable cause, and that this should be taken into account.186 The Tenth Circuit responded to this defense as follows:

We find no merit in defendants' argument. Whether or not probable cause exists is not susceptible to statistical quantification. It represents a judgment call on the part of the officer or officers at the scene taking into account the particular circumstances. Although there are clearly guidelines, much depends on the individual officers' assessment. In the context of assaults, it is possible or perhaps even probable that officers' assessments as to whether probable cause exists are colored by whether the disturbance is domestic or nondomestic. The determination of whether probable cause exists may be subject to the same al-

179. Asmus et al., supra note 17 , at 117.

180. 429 U.S. 252 (1977).

181. See id. at 266-69.

182. Eppler, supra note 8, at 802 (citations omitted).

183. See text accompanying note 150 supra.

184. Specifically, prosecutors have an ethical duty to proceed only in those cases in which they believe they can prove the requisite elements. This creates an ethical as well as legal mandate for prosecutors to go forward in the vast majority of domestic violence cases before them. Interview with Sarah M. Buel, Clinical Professor at the University of Texas School of Law (March 1999).

185. 857 F.2d 690 (10th Cir. 1988).

186. See id. at 695. 
legedly unconstitutional policy that leads to the discrepancy in arrest rates between domestic and nondomestic situations here. In other words, the determination of whether or not probable cause exists and the decision to arrest may present essentially the same issue. 187

This argument applies identically to the concept of prosecutorial discretion as it does to the determination of probable cause. A prosecutor's personal biases affect his impression of a case and of whether it is worth going forward. An argument for prosecutorial discretion in domestic violence cases begs the question to be determined.

Advocates of equal protection claims against the police often focus on the fact that the women in many of the cases asked for help and were still not protected.188 As egregious as this type of police behavior is, we must also protect those victims who do not, or cannot, seek assistance. To do otherwise is to discriminate between levels of victimization, helping only those who are strong enough to help themselves, and leaving behind the truly subjugated. This is contrary to the provision of police protection. Furthermore, "[m]ost crime victims distrust the system,"189 but we still require them to prosecute, or do it without them if necessary. Indeed, in cases where a domestic violence victim's safety is in jeopardy, making a case without her assistance should be the prosecutor's main focus. Prosecutors should be supportive of abuse victims' fears, and when appropriate refer them to a safe place, "but we should never allow the victim's level of cooperation to be the sole or primary factor in deciding whether to prosecute."190 This would not be in tune with how we deal with other crime victims, and "[a]llowing women to step out of the criminal process can further solidify their perception that the criminal justice system marginalizes their concerns."191 Moreover, battery itself cannot legally be consented to, 192 which is essentially what is happening when we "respect the wishes" of battered women not to prosecute.

Finally, weak prosecutorial effort causes direct harm to the victims of domestic violence. It affects the batterer's behavior, the police response level, and the victim's own choices. First, if the batterer knows that he will not be held accountable for his actions, he is more likely to continue the

187. Id. at 692-93.

188. See, e.g., Hathaway, supra note 11, at 691 ("It is crucial, therefore, that victims who do seek assistance from the police and the courts are able to obtain protection.").

189. Hanna, supra note 9, at 1890.

190. Id. at 1891.

191. Id. at 1882.

192. See State v. Brown, 381 A.2d 1231, 1232 (N.J. Super. Ct. App. Div. 1977) ("[A] victim cannot consent to the infliction of an atrocious assault and battery on his person and thus effectively bar the prosecution of his attacker.”); People v. Gray, 36 Cal. Rptr. 263, 265 (Cal. Dist. Ct. App. 1964) ("[I]t is no defense to assert that the victim consented to an assault upon her . ..."). 
abuse. ${ }^{193}$ Studies have shown that no-drop policies significantly reduce the likelihood of future violence and murder.194 Second, police behavior is affected by prosecutorial decisions. "[P]olice may try to justify their failure to arrest batterers as a waste of time and resources because battered women often drop the charges against their assailants. Thus police may defend their policy as substantially related to the important state interest of using limited resources most efficiently." 195 This is not really a defense, but rather a passing of the buck to the District Attorney's office of responsibility for the discrimination. A no-drop policy would resolve this dilemma. Moreover, if the police know that the prosecutor must go forward regardless of the cooperation of the victim, they will probably conduct more thorough investigations while on the scene in order to gather better evidence. Third, lack of prosecutorial effort discourages the victim from asking for help. Statistics show that one of the primary reasons that women do not report domestic violence is the ineffectiveness of legal remedies.196 Victims' reluctance stems as much from the treatment they receive from the legal system as from their batterers. Prosecutors' lack of commitment often "tacitly and overtly discourage[s] victims."' 197 The problem has been called "a self-fulfilling prophesy."198 The prosecutors drop because they expect the victim not to cooperate, and the victims do not cooperate because the prosecutors seem ready to drop. As such, prosecutorial policy greatly impacts the problem of domestic violence.

For all of the reasons discussed in this note, the remaining jurisdictions that have not already done so should implement a no-drop policy for the prosecution of domestic crimes. This policy should be implemented in conjunction with careful ad hoc consideration of victim safety in order to determine how to proceed in each case. This is the best way to ensure that the equal protection of the laws will be provided as required by the Fourteenth Amendment to the Constitution of the United States.

193. See Hanna, supra note 9, at 1892 ("A weak prosecution encourages violence if the batterer knows he will not be held accountable.").

194. See notes 69-120 supra and accompanying text.

195. Eppler, supra note 8, at 795.

196. See Culliton, supra note26, at 508.

197. Corsilles, supra note 31 , at 865.

198. Id. at 866. 
